\title{
Production of lettuce with brackish water in NFT hydroponic system
}

\section{Produção de alface em sistema hidropônico NFT com águas salobras}

\author{
Jucicléia Soares da Silva ${ }^{1 *}$; Vital Pedro da Silva Paz²; Tales Miler Soares ${ }^{3}$; Willian \\ Fernandes de Almeida ${ }^{4}$; Joseane Pereira Fernandes ${ }^{5}$
}

\begin{abstract}
Groundwater reserves in the semi-arid regions, which are mostly brackish, could be used to meet local water demands. Hydroponic cultivation is an alternative of rational use of water. Thus, the objective of this work was to evaluate the technical feasibility of using brackish groundwater in the semi-arid region of Bahia and Recôncavo of Bahia for hydroponic production of curly lettuce cv. 'Verônica' and purple lettuce cv. 'Quatro Estações'. The experiment was conducted in a greenhouse in the city of Cruz das Almas, Bahia State, in a randomized block experimental design, composed of seven treatments [T1- public-supply water; T2- water from the well of UFRB; T3- reject water from the well of Cruz das Almas; T4- water from the well of Sapeaçu; T5- reject water from the well of Sapeaçu; T6- reject water from the well of Conceição do Coité and T7- artificially salinated water $(\mathrm{NaCl})]$ and six replicates in an experimental hydroponic structure using the nutrient film technique (NFT). The following variables were analyzed: number of leaves, shoot fresh matter, shoot length, root length, shoot dry matter, and root dry matter. Relative shoot dry matter production in curly lettuce increased by 1,5 , and $2 \%$ in the treatments T2, T3, and T4, respectively, whereas in purple lettuce, the increments were 10,1 , and $20 \%$, respectively, for the same treatments. The use of brackish groundwater from the deep tubular wells of the Federal University of Recôncavo da Bahia and Sapeaçu and desalination reject water from the tubular well of Cruz das Almas proved to be technically feasible for hydroponic lettuce production.
\end{abstract}

Key words: Hydroponics. Lactuca sativa L.. Groundwater. Water salinity.

\section{Resumo}

As reservas hídricas subterrâneas existentes na região semiárida, na maioria salobras, poderiam ser utilizadas quando disponíveis para atender a demanda hídrica local. O cultivo hidropônico é uma alternativa de exploração racional de água. Com isso, o objetivo do trabalho foi avaliar a viabilidade técnica da utilização de águas subterrâneas salobras do Semiárido e do Recôncavo Baiano na produção hidropônica de alface crespa cv. Verônica e alface lisa repolhuda roxa cv. Quatro Estações. O experimento foi conduzido em casa de vegetação, no Município de Cruz das Almas, Bahia, em delineamento experimental em blocos aleatorizados, composto por sete tratamentos [T1 - água de abastecimento; T2 - água do poço da UFRB; T3 - rejeito do poço do Município de Cruz das Almas; T4 - água do

1 Pós-Doutoranda, Programa de Pós-Graduação em Engenharia Agrícola, Universidade Federal do Recôncavo da Bahia, UFRB, Cruz das Almas, BA, Brasil. E-mail: jucicleiass@gmail.com

2 Prof. Titular, Núcleo de Engenharia de Água e Solo, UFRB, Cruz das Almas, BA, Brasil. E-mail: vpspaz@gmail.com

3 Prof. Adjunto, Núcleo de Engenharia de Água e Solo, UFRB, Cruz das Almas, BA, Brasil. E-mail: talesmiler@gmail.com

4 Pós-Doutorando, Programa de Pós-Graduação em Engenharia Agrícola, UFRB, Cruz das Almas, BA, Brasil. E-mail: wifatec@ yahoo.com.br

5 Discente, Curso de Mestrado, Programa de Pós-Graduação em Microbiologia Agrícola, UFRB, Cruz das Almas, BA, Brasil. E-mail: joysejoys@yahoo.com.br

Aurthor for corespondence 
poço do Município de Sapeaçu; T5 - rejeito do poço de Sapeaçu; T6- rejeito do poço do Município de Conceição do Coité e T7 - água salinizada artificialmente $(\mathrm{NaCl})]$, com 6 repetições, em estrutura hidropônica experimental com a técnica do fluxo laminar de nutrientes (NFT). Foram analisadas as seguintes variáveis: número de folhas, massa de matéria fresca da parte aérea, comprimento da parte aérea, comprimento da raiz, massa de matéria seca da parte aérea e da raiz. A produção relativa da massa de matéria seca da parte aérea da alface crespa teve incremento nos tratamentos T2, T3 e T4 de 1,5 e $2 \%$, respectivamente. Na produção relativa da alface roxa ocorreu incremento de 10,1 e $20 \%$, respectivamente, para os mesmos tratamentos. A utilização de águas subterrâneas salobras exploradas dos poços tubulares profundos da UFRB, de Sapeaçu e o rejeito da dessalinização do poço de Cruz das Almas no Recôncavo Baiano, mostrou-se viável tecnicamente para produção de alface.

Palavras-chave: Hidroponia. Lactuca sativa L.. Águas subterrâneas. Salinidade.

\section{Introduction}

Currently, about one third of the rural population in developing countries live in arid and semi-arid regions, which encompass $54 \%$ of the agricultural area worldwide. Approximately 1 billion people are subjected to water scarcity (HOGAN; TOLMASQUIM, 2001; ROCHA; SOARES, 2015).

Approximately $11 \%$ of the Brazilian territory can be classified as semi-arid regions, distributed throughout the states Minas Gerais, Bahia, Sergipe, Alagoas, Piauí, Pernambuco, Paraíba, Rio Grande do Norte, and Ceará. Mean total rainfall is $750 \mathrm{~mm}$, ranging between 500 and 2,000 $\mathrm{mm}$, depending on the locality. There is a distinct rainy season from January to July, but because of the irregular distribution, high evaporation rates, and wide interannual variability, the crop water demands are not met (MARENGO; BERNASCONI, 2015; MONTENEGRO et al., 2010; SILVA et al., 2011). However, these regions have several underground water reserves which could be exploited.

The semi-arid regions are covered by rocks from the crystallin basement, and the wells used to draw groundwater generally have a low flow rate and brackish waters, limiting their use in agriculture; there is also a high salinization potential for soils and receiving waters (AUDRY; SUASSUNA, 1995; BENJAMÍN et al., 2005; CIRILO, 2008; COSTA et al., 2006; REBOUÇAS, 2002).

Given the increasing demand for water, groundwater is being used at a progressing rate, even in regions with higher availability of goodquality surface and subsurface waters, such as in the Recôncavo of Bahia.

The use of groundwater in agriculture may pose severe risks to the environment, such as soil salinization, resulting in significant yield loss.

One alternative that may favor the use of brackish waters for human consumption is their desalination, and in Brazilian semi-arid regions, reverse osmosis is the main technology (CARVALHO et al., 2004; CIRILO, 2008; PORTO et al., 2001; SOARES et al., 2006). However, the desalination process produces both good-quality water and reject water, whose salinity may be twice as high as the initial concentration.

Desalination by reverse osmosis produces approximately $40 \%$ good-quality water (fresh water) and $60 \%$ reject water. Therefore, a large volume of reject water is generated, and in almost all cases, this water is being disposed of in the soil, without any treatment; the results is a high accumulation of salts in the superficial soil layers (KARAGIANNIS; SOLDATOS, 2008; PORTO et al., 2001; TSIOURTIS, 2001).

Several studies (ALVES et al., 2011; DIAS et al., 2011; PAULUS et al., 2010; SANTOS et al., 2010; SOARES et al., 2010) have shown that it is possible to use brackish waters to produce lettuce hydroponically, and the tolerance to salts may be higher than that obtained in conventional cultivation in soil. 
Given this situation, hydroponics presents itself as an alternative that may promote better conditions for plant growth (SAVVAS, 2002). Among its advantages, efficient water use and the reduced or inexistent contribution of the matric potential over the total water potential (SIDDIQI et al., 1998; VAN OS, 1999; VAN OS et al., 2002) may contribute to a higher tolerance to salinity.

Studies have been conducted to make the use of this desalination byproduct for productive purposes viable, promoting both adequate destination and an alternative income for rural farmers in the communities benefited by the use of desalinators.

In this context, this study evaluated the technical viability of using brackish groundwater in the semiarid region of Bahia and Recôncavo of Bahia for hydroponic production of lettuce.

\section{Material and Methods}

The study was carried out from July 5 to August 29, 2011, in a greenhouse at the Experimental Unit of the Water and Soil Engineering Center (NEAS) of the Federal University of Recôncavo da Bahia (UFRB), in the municipality of Cruz das Almas, Bahia, Brazil (1240'19" S, 3906'23" W, mean elevation $225 \mathrm{~m})$.

The climate of the region is classified as humid to sub-humid, with annual means of relative air humidity and mean temperature of $80 \%$ and $24.1^{\circ} \mathrm{C}$, respectively; mean annual rainfall is $1,170 \mathrm{~mm}$ (ALMEIDA, 1999).

The greenhouse used had an arched top covered by a $150-\mu \mathrm{m}$-thick anti-ultraviolet plastic film, while the sides were covered by white screens.

The hydroponic structure comprised 42 experimental units, based on the one described by Alves et al. (2011) and Soares et al. (2009). Each plot represented one independent NFT (nutrient film technique) hydroponic system, composed by the following items: plastic container with a capacity for $50 \mathrm{~L}$ of nutrient solution; one self- cooling circulation electric pump with plastic internal components to avoid corrosion by the nutrient solution, and one hydroponic profile made of polypropylene with anti-ultraviolet additive, with a diameter of $0.075 \mathrm{~m}$, an length of $3 \mathrm{~m}$, and nine holes with a spacing of $0.30 \mathrm{~m}$.

The hydroponic profiles were installed at a height of $1.0 \mathrm{~m}$ from the soil surface, with a $4 \%$ slope. The profiles had a spacing of $0.5 \mathrm{~m}$, and a $0.9 \mathrm{~m}$ wide gap was left between the pairs of plots to facilitate the operations. The floor was covered by a grey polyester geotextile $\left(\right.$ Bidim $\left.^{\circledR}\right)$.

Individual automatic water-supply systems were set for each plot, made of PVC pipe with a diameter of $0.2 \mathrm{~m}$. The systems allowed the automatic exit of water to the nutrient solution container through a floating valve, maintaining the volume and appropriate concentration of the solution for each treatment. The water supply tank had a ruler fixed close to a transparent hose.

Nutrient solution was pumped from the tank to the highest part of the hydroponic profile by the electric circulation pump, actuated by a digital timer. Throughout the experiment, the plots were irrigated from $06: 00 \mathrm{~h}$ to 11:00 h. Nutrient solution recirculation was performed at a duration of $15 \mathrm{~min}$ and an interval of $15 \mathrm{~min}$; from 11:00 h to $14: 00 \mathrm{~h}$, nutrient solution circulation was continuous; from 14:00 $\mathrm{h}$ to $19: 00 \mathrm{~h}$, recirculation was carried out every 15 minutes; at 21:00 h, 23:00 h, and 02:00 h, 15-min recirculation of the nutrient solution was performed.

Air and nutrient solution temperatures were monitored by copper-constantan thermocouples ( $\mathrm{T}$ type), interconnected to a datalogger (CR1000); readings were taken every $15 \mathrm{~min}$ and stored.

Seeds of two lettuce varieties, curly lettuce 'Verônica' and purple loose-leaf lettuce 'Quatro Estações', were sown in phenolic foam. After sowing, the cells were maintained for 24 hours in a dark environment and then transferred to the nursery, where they remained for 30 days. Initially, plants 
were irrigated only with public-supply water (fresh water) until the $4^{\text {th }}$ day after sowing (DAS); after this period, they were irrigated with $100 \%$ nutrient solution based on the nutrient formulation of Furlani et al. (1999), with an electrical conductivity (EC) of approximately $2.0 \mathrm{dS} \mathrm{m}^{-1}$.

Prior to definitive transplantation, thinning was performed to leave only one lettuce seedling per cell. Transplantation to the growth benches occurred at 30 DAS by placing six plants in each profile, three of curly lettuce and three of purple lettuce. At transplantation, the curly lettuce had four true leaves, while the purple lettuce had seven.

Treatments were selected based on the records of the Environmental Engineering Company of Bahia (CERB), considering three deep tubular wells with brackish groundwater. Two of them are found in the
Recôncavo of Bahia, namely: a well installed in the Brito community in the municipality of Sapeaçu and a well installed in the Caminhoá locality in the municipality of Cruz das Almas. In the semi-arid region of Bahia, a well was selected in the Ipiranga locality in the municipality of Conceição do Coité.

All these wells are equipped with reverse osmosis desalinators and provided the reject water for the present study, namely wastewater from desalination. Besides these three sources of brackish groundwaters, evaluations were also made for brackish water obtained directly from a deep tubular well installed at the UFRB Campus in Cruz das Almas.

The chemical composition of the different groundwaters from deep tubular wells is described in Table 1.

Table 1. Analysis of chemical compositions of the different groundwaters from the deep tubular wells.

\begin{tabular}{|c|c|c|c|c|}
\hline \multirow{2}{*}{ Parameters } & \multicolumn{4}{|c|}{ Groundwaters from the deep tubular wells } \\
\hline & UFRB & Cruz das Almas & Sapeaçu & Conceição do Coité \\
\hline Total residue (mg/l) & 510.00 & 1900.00 & 1910.00 & 6568.00 \\
\hline Chloride $(\mathrm{mg} / \mathrm{l} \mathrm{Cl})$ & 117.00 & 722.00 & 568.00 & 2575.00 \\
\hline Hardness $\left(\mathrm{mg} / 1 \mathrm{CaCO}_{3}\right)$ & 240.00 & 527.00 & 693.00 & 3269.00 \\
\hline Nitrate $\left(\mathrm{mg} / \mathrm{l} \mathrm{N}-\mathrm{NO}_{3}\right)$ & 0.926 & 2.90 & 0.98 & 7.50 \\
\hline AlkalHCO $\left(\mathrm{mg} / \mathrm{l} \mathrm{CaCO}_{3}\right)$ & 179.00 & 144.00 & 262.00 & 354.00 \\
\hline AlkalCO (mg/l CaCO3) & 10.70 & 18.90 & 0.00 & 0.00 \\
\hline AlkalOH (mg/l CaCO 3$)$ & ND & ND & 0.00 & 0.00 \\
\hline Calcium (mg/l $\left.\mathrm{CaCO}_{3}\right)$ & 68.80 & 162.00 & 291.00 & 1217.00 \\
\hline Conductivity $(\mu \mathrm{S} / \mathrm{cm})$ & 855.00 & 2620.00 & 2510.00 & 7620.00 \\
\hline Color (mg/1 Pt-Co) & $<5.00$ & $<5.00$ & 150.00 & $<5.00$ \\
\hline $\operatorname{Iron}(\mathrm{mg} / \mathrm{l} \mathrm{Fe})$ & 0.13 & ND & 3.70 & $<\mathrm{MDL}$ \\
\hline Fluoride (mg/l F) & 0.173 & 1.43 & 0.43 & 0.63 \\
\hline Magnesium (mg/l Mg) & 41.50 & 88.60 & 97.70 & 397.00 \\
\hline Nitrite $\left(\mathrm{mg} / 1 \mathrm{~N}-\mathrm{NO}_{2}\right)$ & ND & 0.01 & $<\mathrm{MDL}$ & $<\mathrm{MDL}$ \\
\hline $\mathrm{PH}$ & 8.24 & 7.75 & 7.15 & 7.27 \\
\hline Silica $\left(\mathrm{mg} / 1 \mathrm{SiO}_{2}\right)$ & 88.70 & 60.90 & 64.50 & 40.40 \\
\hline Sulfate $\left(\mathrm{mg} / 1 \mathrm{SO}_{4}\right)$ & 62.70 & 86.20 & 219.00 & 217.00 \\
\hline Turbidity (NTU) & 0.76 & 1.84 & 29.40 & 9.33 \\
\hline Acidity $\left(\mathrm{mg} / 1 \mathrm{CaCO}_{3}\right)$ & ND & & 11.90 & 8.83 \\
\hline Potassium (mg/l) & 6.20 & & 87.50 & 25.00 \\
\hline Sodium (mg/l) & 81.60 & & 212.00 & 500.00 \\
\hline
\end{tabular}


The experiment was composed of seven treatments and six replicates, arranged in randomized blocks, in a total of 42 plots, each of which contained six plants of the two lettuce varieties, three of curly lettuce 'Verônica' and three of purple loose-leaf lettuce 'Quatro Estações', according to Table 2 and described below. The treatments were as follows:

Table 2. Electrical conductivity of water (W) and nutrient solution (NS), hydrogen potential ( $\mathrm{pH}$ ) of water before correction $(\mathrm{W})$ and nutrient solution after first correction $\left(\mathrm{AFC}_{\mathrm{NS}}\right)$ and second correction $\left(\mathrm{ASC}_{\mathrm{NS}}\right)$, as a function of the type of water.

\begin{tabular}{ccccccc}
\hline \multirow{2}{*}{ Treatment } & \multirow{2}{*}{ Types of water } & \multicolumn{2}{c}{$---\mathrm{EC}\left(\mathrm{dS} \mathrm{m} \mathrm{m}^{-1}\right)---$} & \multicolumn{2}{c}{$---------\mathrm{pH}^{----------}$} \\
\cline { 3 - 7 } & & $\mathrm{W}$ & $\mathrm{NS}$ & $\mathrm{W}$ & $\mathrm{AFC}_{\mathrm{NS}}$ & $\mathrm{ASC}_{\mathrm{NS}}$ \\
\hline $\mathrm{T} 1$ & Embasa (Control) & 0.26 & 2.09 & 7.10 & 5.50 & 5.80 \\
$\mathrm{~T} 2$ & UFRB - Well & 1.28 & 2.94 & 8.60 & 6.10 & 5.80 \\
$\mathrm{~T} 3$ & Cruz das Almas - Reject & 2.86 & 5.00 & 8.80 & 6.50 & 5.77 \\
$\mathrm{~T} 4$ & Sapeaçu - Well & 3.06 & 4.85 & 9.00 & 6.50 & 5.77 \\
$\mathrm{~T} 5$ & Sapeaçu - Reject & 5.44 & 7.08 & 9.30 & 6.70 & 5.78 \\
$\mathrm{~T} 6$ & Conceição do Coité - Reject & 10.19 & 11.17 & 9.00 & 6.70 & 5.73 \\
$\mathrm{~T} 7$ & $\mathrm{NaCl}$ & 10.25 & 11.80 & 7.10 & 6.10 & 5.78 \\
\hline
\end{tabular}

T1 (Control) - public-supply water from the Bahia State Water and Sanitation Company S.A (Embasa); T2 (UFRB well) - groundwater from well installed at UFRB in Cruz das Almas; T3 (reject water from the well of Cruz das Almas) desalination reject water from well perforated in the Caminhoá district, in Cruz das Almas; T4 (water from the well of Sapeaçu) - simulates natural water from the deep tubular well located at the Brito locality, municipality of Sapeaçu, Recôncavo of Bahia, obtained by diluting (50\%) the reject water (reverse osmosis desalination) produced in this site (T5) with the same fresh water of treatment $\mathrm{T} 1$; T5 (reject from the well of Sapeaçu) - desalination reject water from the well of Sapeaçu; T6 (reject water from the well of Conceição do Coité) desalination reject water from the well of the municipality of Conceição do Coité; and T7 $(\mathrm{NaCl})$ - water artificially salinated by adding $5.96 \mathrm{~g} \mathrm{~L}^{-1}$ of sodium chloride $(\mathrm{NaCl})$ to fresh water $\left(0.26 \mathrm{dS} \mathrm{m}^{-1}\right)$, aiming at a salinity level equivalent to that of the reject water from Conceição do Coité (T6).

The nutrient solution in all treatments was prepared with the same amount of fertilizers, following the recommendation of Furlani et al. (1999) for hydroponic cultivation of leafy vegetables.

Each plot received a $0.05 \mathrm{~m}^{-3}$ volume of brackish water to prepare the nutrient solution. Before preparing the nutrient solutions, the $\mathrm{pH}$ of each water was corrected with hydrochloric acid. This procedure was performed in all waters, because their $\mathrm{pH}$ levels were not within the ideal range of 5.5 to 6.5. Using water and nutrient solutions with higher $\mathrm{pH}$ values results in precipitation of iron and other micronutrients (except molybdenum), whereas at a $\mathrm{pH}$ below 5.5, micronutrients are excessively absorbed.

Transpiration water was replenished using brackish water with the same quality of that used to prepare the nutrient solution of each treatment.

During the experiment, samples of nutrient solutions were collected in all plots to determine and monitor electrical conductivity $\left(\mathrm{EC}_{\mathrm{NS}}\right)$ and $\mathrm{pH}$.

Lettuce plants were harvested at 25 days after 
transplanting (DAT) by collecting two plants of each variety per plot. The following variables were evaluated: number of leaves (NL) longer than $3 \mathrm{~cm}$; shoot fresh matter (SFM), measured on precision scale $(0.00001 \mathrm{~kg})$; shoot length (SL) and root length (RL), both determined using a ruler.

After pre-drying for 24 hours, lettuce plants were dried in a forced-air oven at a temperature of $72^{\circ} \mathrm{C}$ until constant weight. Shoot dry matter (SDM) and root dry matter (RDM) were determined on a precision scale and used to calculate total dry matter (TDM). In addition, plants were visually assessed to detect symptoms of toxicity and/or nutritional deficiency.

Relative production of lettuce plants for each brackish water was compared with that of the control treatment (fresh water), was calculated using Eq. (1):

$$
R P=\left(\frac{S F M_{\text {TREAT }}}{S F M_{\text {CONTROL }}}-1\right) \times 100
$$

where:

RP - Relative production (\%);

$\mathrm{SFM}_{\text {TREAT }}$ - Shoot fresh matter of a given treatment $(\mathrm{kg})$;

$\mathrm{SFM}_{\text {CONTROL }}$ - Shoot fresh matter of the control treatment $(\mathrm{kg})$.

Yield and growth data were subjected to analysis of variance, and means were compared by Tukey's test at 0.05 probability level, using the statistical program SAS.

\section{Results and Discussion}

Air and nutrient solution temperatures along the experiment are presented in Figure 1, which shows that air temperature $\left(\mathrm{T}_{\text {air }}\right)$ varied from 17 to $35^{\circ} \mathrm{C}$ inside the greenhouse. Air temperature along the experiment showed a maximum of $35^{\circ} \mathrm{C}$, a mean of $23^{\circ} \mathrm{C}$, and a minimum of $17^{\circ} \mathrm{C}$. Nutrient solution temperature ranged from 19 to $31^{\circ} \mathrm{C}$, with a maximum of $31^{\circ} \mathrm{C}$, a mean of $24^{\circ} \mathrm{C}$, and a minimum of $19^{\circ} \mathrm{C}$.

Figure 1. Air and nutrient solution temperatures along lettuce cycle.

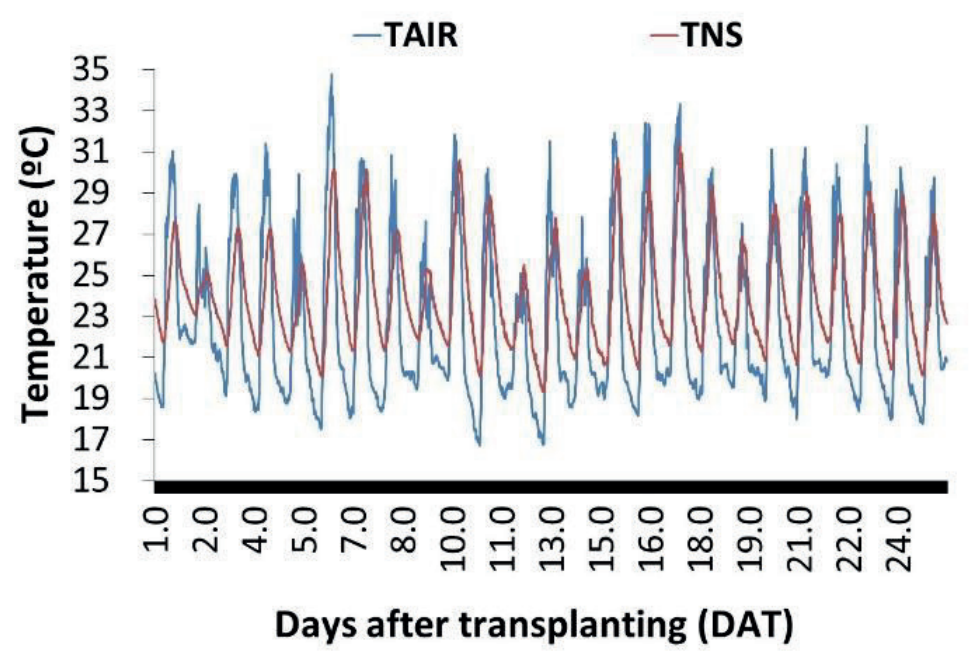


Throughout the experiment, air and nutrient solution temperatures greenhouse differed from the values recommended by Martinez (2006) for vegetable production $\left(15\right.$ to $\left.25^{\circ} \mathrm{C}\right)$.

Nutrient solution temperature was higher than the ideal temperature for vegetables, with recommended 18 to $24^{\circ} \mathrm{C}$ in the hottest periods and 10 to $16^{\circ} \mathrm{C}$ in the coldest periods, according to
Alberoni (1998).

Even after initial $\mathrm{pH}$ correction for cultivation, a second correction of the nutrient solutions was necessary at 8 DAT, and all solutions were corrected to $\mathrm{pH} 5.8$, including the treatments with fresh water (T1) and water artificially salinated with $\mathrm{NaCl}$ (T7), for which no $\mathrm{pH}$ oscillation was expected (Figure 2A), as demonstrated in Table 2.

Figure 2. pH (A) and electrical conductivity (B) of the nutrient solutions over time, as a function of the type of water.

A.

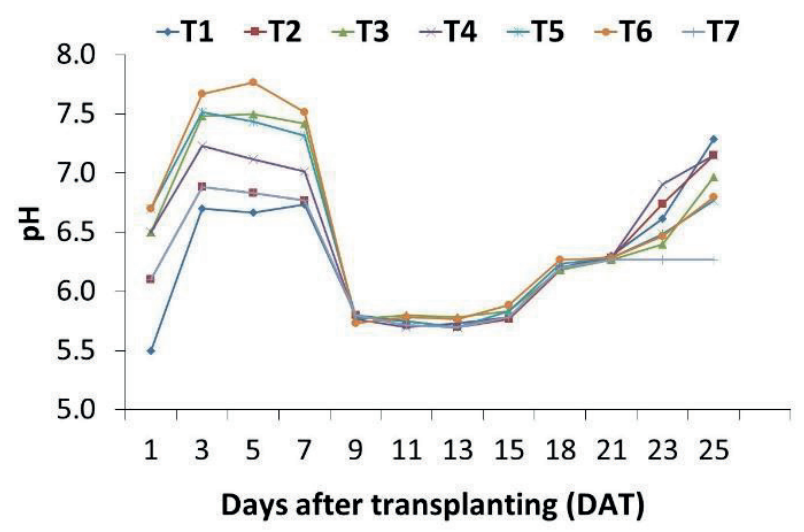

From 9 to 15 DAT, the $\mathrm{pH}$ stabilized within the ideal range. From this point on, the solutions became alkaline, but remained within the ideal range until 21 DAT. Until the end of the cycle (25 $\mathrm{DAT}$ ), the $\mathrm{pH}$ increased beyond the ideal range, except for the nutrient solution artificially salinated. However, repeated correction at the end of the cycle was considered unnecessary (Figure 2A).

Electrical conductivity values of the nutrient solution before and after the experiment are presented in Figure 2B. The salinity levels in the nutrient solutions prepared with the water from the UFRB well (T2) and reject from the Cruz das Almas well (T3) increased only by 0.37 and $0.56 \mathrm{dS}$ $\mathrm{m}^{-1}$, respectively, compared with the initial values. In contrast, the rejects from Sapeaçu (T5) and Conceição do Coité (T6) and the artificially salinated water (T7) led to more expressive increments in the

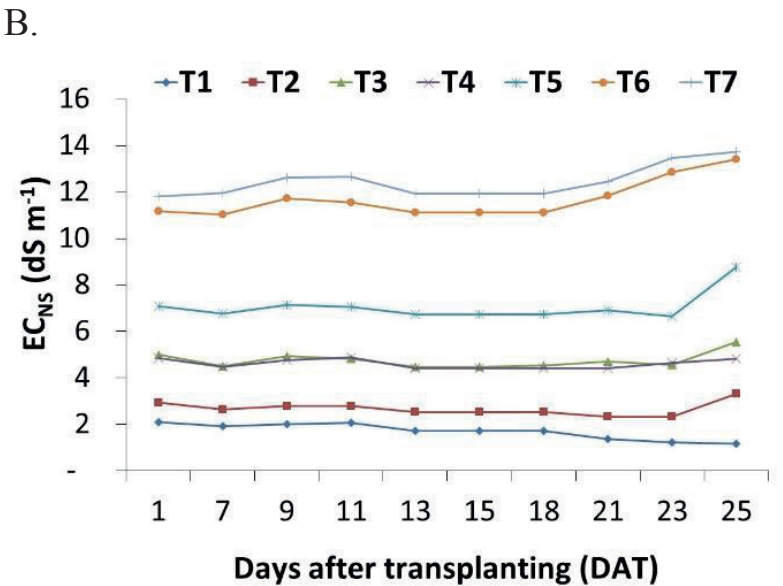

final salinity levels, equal to $1.68,2.25$, and $1.93 \mathrm{dS}$ $\mathrm{m}^{-1}$, respectively. In the treatment with fresh water (T1), nutrient solution salinity tended to decrease along the cycle, and its $\mathrm{EC}_{\mathrm{NS}}$ showed a reduction of $0.93 \mathrm{dS} \mathrm{m}^{-1}$.

In the treatment with artificially salinated water (T7), $\mathrm{pH}$ was not expected to recover because the hydrolysis of a salt formed by ions of strong acid and strong base, such as $\mathrm{NaCl}$, results in a solution with $\mathrm{pH}$ balance (SILVA et al., 2001). The alteration of $\mathrm{pH}$ in this treatment is probably due to the quality of the fresh water used in the preparation.

Regarding the brackish waters from the wells and their desalination rejects, the increase in $\mathrm{pH}$ can be explained by the presence of carbonates and bicarbonates, which impart buffering capacity to the solution, as reported by Santos et al. (2010). 
The increase of salinity in the treatments with brackish water, rejects, and artificially salinated water can be explained by the accumulation of ions not absorbed by the vegetables. Obviously, the higher the concentration of these ions in the replacement water, the higher the salinization level, as already reported by other authors in studies using brackish water in NFT hydroponic systems for lettuce production (ALVES et al., 2011; PAULUS et al., 2010; SANTOS et al., 2010; SOARES et al., 2010).

The salinity level in the nutrient solution produced with water from the Sapeaçu well (T4) remained virtually constant along the cycle, differing from the results found by Alves et al. (2011), Paulus et al. (2010), and Soares et al. (2010), working with artificial brackish waters, and Santos et al. (2010), working with natural brackish waters, at equivalent levels of salinity.

In the treatment with fresh water (T1), nutrient solution salinity tended to decrease along the cycle, probably due to the consumption of nutrients, which was higher than the low content of salts dissolved in this water (SOARES et al., 2010). A reduction in $\mathrm{EC}_{\mathrm{NS}}$, using fresh water, has also been found by Paulus et al. (2010) and Santos et al. (2010).

The number of leaves (NL) in curly lettuce subjected to the salinity of brackish water from UFRB (T2), reject from Cruz das Almas (T3), and brackish water from Sapeaçu (T4) did not differ from that in the control treatment (T1). The treatments with reject from Sapeaçu (T5), reject from Conceição do Coité (T6), and artificially salinated water (T7) were statistically different from the others, which obtained leaf numbers similar to T1. The number of leaves ranged from 20 to 26 leaves. There was no difference between the treatments for the NL in purple lettuce, which varied from 31 to 37 leaves (Figure 3A). The absence of a water salinity effect on the number of leaves is consistent with the results found by Soares et al. (2010), who grew 'Verônica' curly lettuce at different nutrient concentrations (2.09 to $\left.8.67 \mathrm{dS} \mathrm{m}^{-1}\right)$ in an NFT hydroponic system.

Figure 3. Number of leaves (A) and shoot length (B) of curly and purple lettuces, as a function of the treatments.

A.

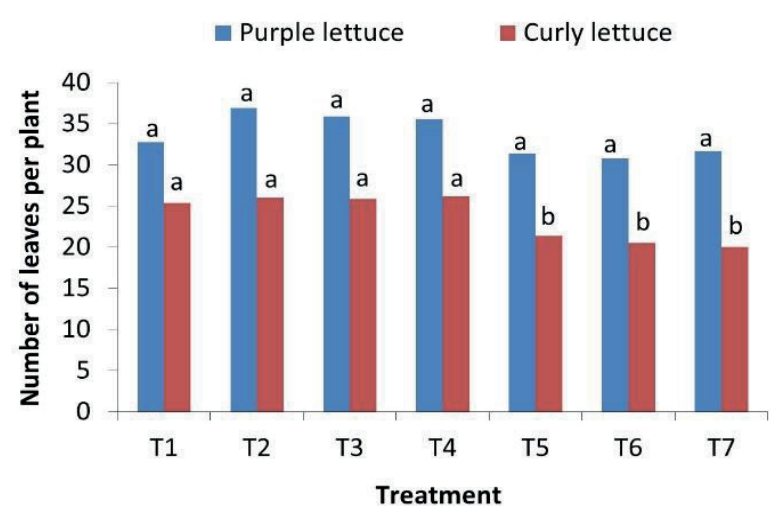

Shoot length (SL) measurements are presented in Figure 3B, with values ranging from 20.3 to 32.6 $\mathrm{cm}$ for curly lettuce and from 21.8 to $37.9 \mathrm{~cm}$ for purple lettuce. For both varieties subjected to water
B.

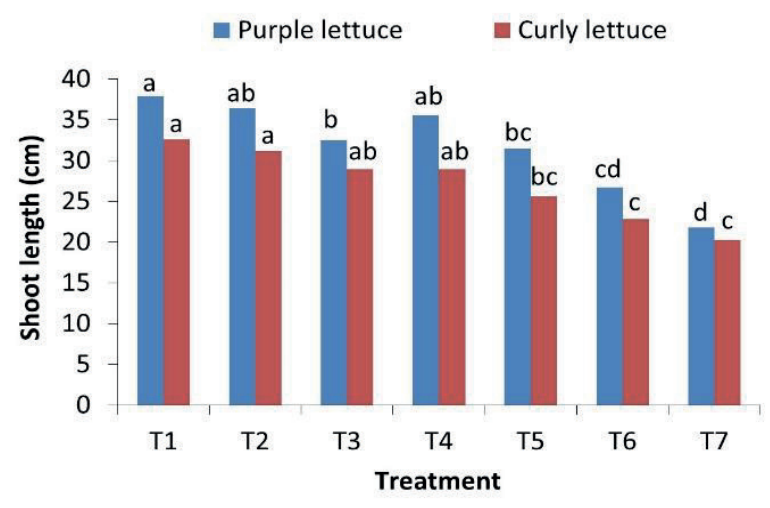

from UFRB (T2) and brackish water from Sapeaçu (T4), no significant differences in SL were found at 0.05 probability level in comparison to the treatment with fresh water (T1); the other treatments differed 
from the treatment with fresh water (T1). Except for the reject from Cruz das Almas (T3), no significant differences in SL were found at 0.05 probability level, compared with the treatment with fresh water (T1), for curly lettuce.

Increased salinity led to a decrease in SL; in other words, the more brackish the water, the lower the shoot length of both lettuce varieties.

Shoot fresh matter (SFM) in curly lettuce varied from 78 to $210 \mathrm{~g}$ (Figure 4A) as a function of the treatments. No differences were observed in the treatments with brackish groundwaters from UFRB (T2), desalination reject from the well of Cruz das Almas (T3), and brackish water from Sapeaçu (T4) compared with the control treatment (T1). The treatments with reject from Sapeaçu (T5), reject from Conceição do Coité (T6), and water artificially salinated with $\mathrm{NaCl}$ (T7) statistically differed from the control (T1); i.e., the increase in nutrient solution salinity caused a reduction in the SFM of curly lettuce.

Figure 4. Shoot fresh matter (A) and relative production (B) of curly and purple lettuces, as a function of the treatments.

A.

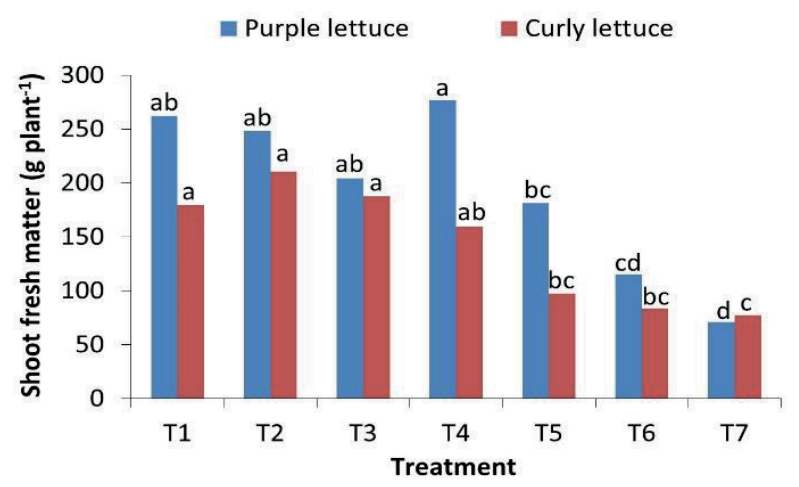

For curly lettuce, there was no statistical difference between the treatments with brackish water from Sapeaçu (T4) and reject from Conceição do Coité (T6). The treatment with water artificially salinated using $\mathrm{NaCl}$ (T7) did not differ statistically from the treatments with reject from Sapeaçu (T5) and reject from Conceição do Coité (T6).

On the other hand, shoot fresh matter (SFM) of purple lettuce varied from 71 to $277 \mathrm{~g}$ (Figure 4A). The treatment with reject from Sapeaçu (T5) did not differ from that with reject from Conceição do Coité (T6), but both led to productions similar to that relative to the water from Sapeaçu (T4). In contrast, there was no difference between water artificially salinated using $\mathrm{NaCl}$ (T7) and reject from Conceição do Coité (T6).
B.

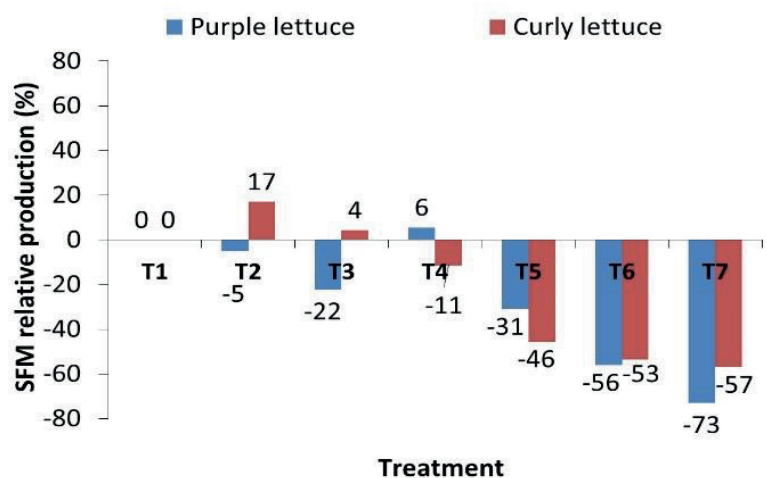

There was a statistical difference in the purple lettuce SFM as a function of the treatments, and the lowest values were found in the treatments with reject from Conceição do Coité (T6) and with water artificially salinated using $\mathrm{NaCl}$ (T7) (Figure 4A). The trends of SFM reduction in the treatments with reject from Conceição do Coité (T6) and water artificially salinated using $\mathrm{NaCl}$ (T7) were similar for both lettuce varieties, but the curly lettuce in the treatment with water from UFRB (T2) obtained an increment of $30 \mathrm{~g}$ compared with the treatment with fresh water (T1), while the purple lettuce in the treatment with brackish water from Sapeaçu (T4) obtained an increment of $15 \mathrm{~g}$ compared with the treatment with fresh water (T1). 
The relative production of SFM increased by 17 and $4 \%$ in curly lettuce in the treatments with water from UFRB (T2) and reject from Cruz das Almas (T3), respectively. For the treatments with brackish water from Sapeaçu (T4), reject from Sapeaçu (T5), reject from Conceição do Coité (T6), and water artificially salinated with $\mathrm{NaCl}$ (T7), the reductions in relative production were $11,46,53$, and $57 \%$, respectively (Figure 4B).

For purple lettuce grown with brackish water from Sapeaçu (T4), there was an increment of $6 \%$ in the relative production of SFM, whereas the treatments with water from the well of UFRB (T2), reject from Cruz das Almas (T3), reject from Sapeaçu (T5), reject from Conceição do Coité (T6), and water artificially salinated with $\mathrm{NaCl}$ (T7) showed reductions of 5, 22, 31, 56, and 73\%, respectively (Figure 4B).

In the treatment with fresh water (T1), lettuce production was higher in terms of shoot fresh matter. Using reject from Conceição do Coité (T6) and water artificially salinated with $\mathrm{NaCl}$ (T7) led to a significantly lower production compared with the use of fresh water (T1), which reveals a significant gradient of production losses for the types of water as salinity levels increase. This behavior has also been observed by other authors studying the use of brackish water in lettuce production in NFT hydroponic system; they found a decline in lettuce production with increasing salinity levels (ALVES et al., 2011; PAULUS et al., 2010; SANTOS et al., 2010; SOARES et al., 2010).

Using rejects from Sapeaçu and Conceição do Coité and water salinated with $\mathrm{NaCl}$ can reduce lettuce yield by half, which can make commercial production unfeasible. Reduction in the spacing between plants, to increase plant density, may compensate the decline in the production per plant.

Shoot dry matter (SDM) ranged between 6.0 and $12.4 \mathrm{~g}$ for curly lettuce and between 5.9 and $13.8 \mathrm{~g}$ (Figure 5A) for purple lettuce at 25 DAT. There was no statistical difference in SDM for the treatments with water from UFRB (T2), reject from Cruz das Almas (T3), and brackish water from Sapeaçu (T4), in comparison to fresh water (T1), for both varieties.

Figure 5. Shoot dry matter (A) and relative production (B) of curly and purple lettuces, as a function of the treatments.

A.

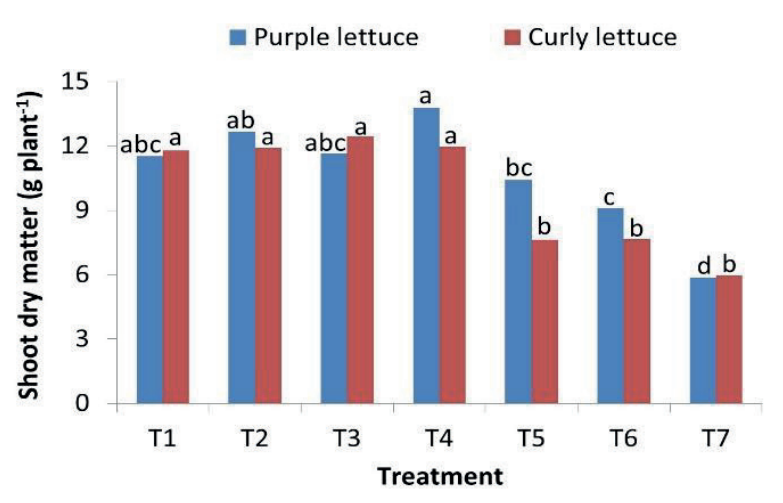

For purple lettuce, the treatments with fresh water (T1), brackish waters (T2 and T4), and rejects (T2, T5, and T6) were statistically different from that with water salinated using $\mathrm{NaCl}$ (T7). The
B.

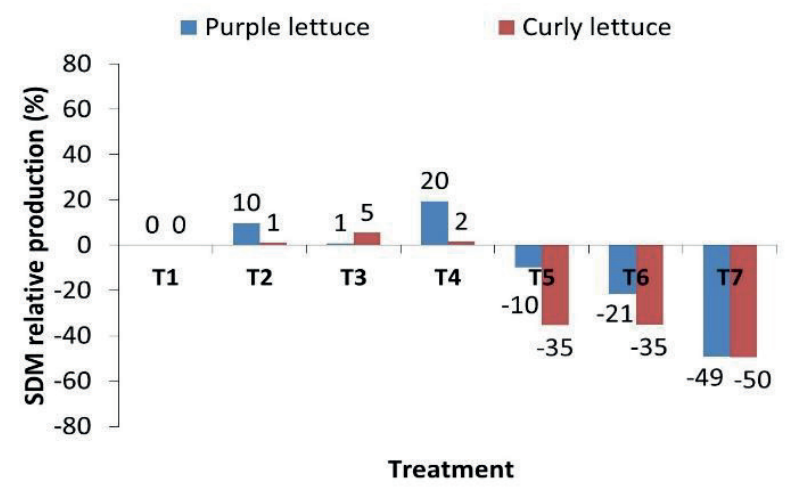

treatment with reject from Sapeaçu (T5) did not differ statistically from that using fresh water (T1) and reject from Conceição do Coité (T6). 
The relative production of SDM of curly lettuce increased by 1.0, 5.0, and 2.0 in the treatments with water from UFRB (T2), reject from Cruz das Almas (T3), and brackish water from Sapeaçu (T4), but decreased by $35.4,35.1$, and $49.5 \%$, in the treatments with reject from Sapeaçu (T5), reject from Conceição do Coité (T6), and water artificially salinated using $\mathrm{NaCl}$ (T7) (Figure 5B).

For purple lettuce, relative SDM production increased by 10,1 , and $20 \%$ in the treatments with water from UFRB (T2), reject from Cruz das Almas (T3), and brackish water from Sapeaçu (T4), whereas the other treatments obtained reductions of 10,21 , and $49 \%$, respectively, for reject from Sapeaçu (T5), reject from Conceição do Coité (T6), and water artificially salinated with $\mathrm{NaCl}$ (T7) (Figure 5B).

The stress caused by the increase in salinity physiologically reduced water absorption by plants and, consequently, reduced their fresh matter content (SOARES, 2007). This factor may explain the lower relative reduction in the production of hydroponic lettuce subjected to increased salinity when dry matter is evaluated instead of fresh matter (ALVES et al., 2011; PAULUS et al., 2010; SANTOS et al., 2010; SOARES et al., 2010).

These results indicate that using brackish waters, depending on their chemical composition, may lead to an increment in lettuce production and that water with a salinity below $3.0 \mathrm{dS} \mathrm{m}^{-1}$ can be technically viable for lettuce cultivation, using the reject from reverse osmosis desalination.

As observed for SFM, SDM was not compromised by the use of natural brackish waters (UFRB and Sapeaçu) and reject from Cruz das Almas compared with the use of fresh water. Conversely, rejects from Sapeaçu and Conceição do Coité, and particularly the artificially salinated water, significantly reduced SDM. These results indicate that the electrical conductivity of the nutrient solution and the water quality significantly affect lettuce yield, corroborating Blat et al. (2011), Casaroli et al. (2003), Domingues et al. (2012), Luz et al. (2006), and Seo et al. (2009).

The presence of nutrient ions in the water from Conceição do Coité led to higher SDM accumulation in purple lettuce compared with the water salinated using $\mathrm{NaCl}$, which was isosmotic, but contained only toxic ions.

According to the root dry matter (RDM) data shown in Figure 6A, the values ranged from 1.61 to $2.40 \mathrm{~g}$ in the curly lettuce 'Verônica' and from 1.3 to $2.6 \mathrm{~g}$ in the purple lettuce 'Quatro Estações' at 25 DAT.

Figure 6. Root dry matter (A) and total dry matter (B) of curly and purple lettuces, as a function of the treatments.

A

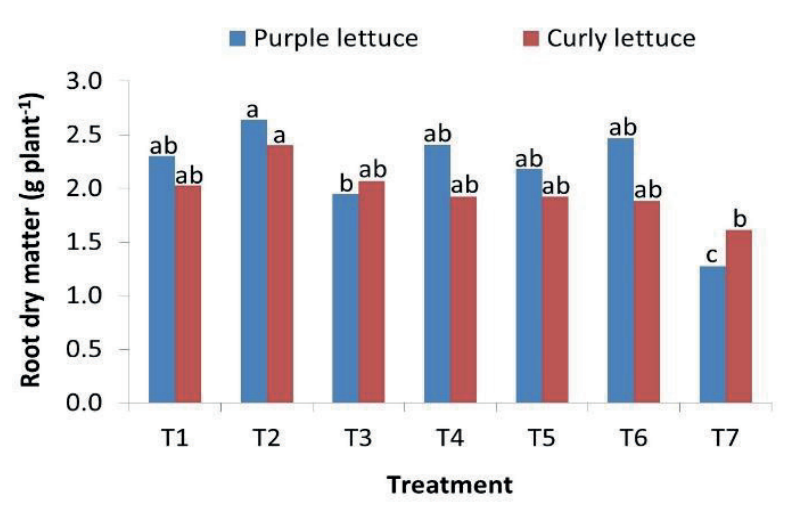

B.

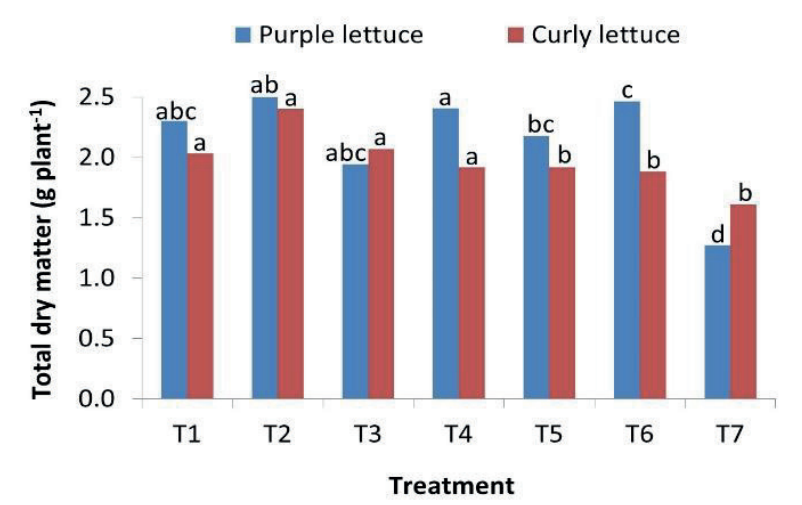


There was no statistical difference in the RDM of curly lettuce for the treatments with water from UFRB (T2), reject from Cruz das Almas (T3), brackish water from Sapeaçu (T4), reject from Sapeaçu (T5), and reject from Conceição do Coité (T6) compared with fresh water (T1). For purple lettuce, a significant difference was observed between the treatments with fresh water (T1) and water salinated with $\mathrm{NaCl}$, whereas the treatment with fresh water (T1) did not differ from the other treatments. In addition, artificially salinated water led to lower RDM values (Figure 6A).

In the already cited works of Paulus et al. (2010) and Soares et al. (2007), there was no effect of water salinity on the root system of 'Verônica' lettuce in the NFT hydroponic system. In general, studies with brackish water in hydroponics found no reduction of the lettuce root system.

Total dry matter (TDM) data are presented in Figure 6B and ranged from 0.0076 to $0.014 \mathrm{~kg}$ for curly lettuce 'Verônica' and from 0.0072 to 0.016 kg for purple lettuce 'Quatro Estações' at 25 DAT.

There were no statistical differences at the 0.05 probability level for TDM in the treatments with water from UFRB (T2), reject from Cruz das Almas (T3), and brackish water from Sapeaçu (T4) compared with fresh water (T1). No statistical difference was found between the treatments with reject from Sapeaçu (T5), reject from Conceição do Coité (T6), and water artificially salinated with $\mathrm{NaCl}$ (T7), although these treatments differed from the control (T1) for curly lettuce. For purple lettuce, the treatment with water artificially salinated with $\mathrm{NaCl}$ (T7) differed from all the others in terms of TDM (Figure 6B).

Root length (RL) varied between 40 and $56 \mathrm{~cm}$ for curly lettuce and between 43 to $59 \mathrm{~cm}$ for purple lettuce (Figure 7). Water salinity had no significant effect on root length, compared with the control, demonstrating that the reduction in plant growth was more associated with the salinity effect on the shoots than on the root system.

Figure 7. Root length for curly lettuce and purple lettuce, as a function of the treatments.

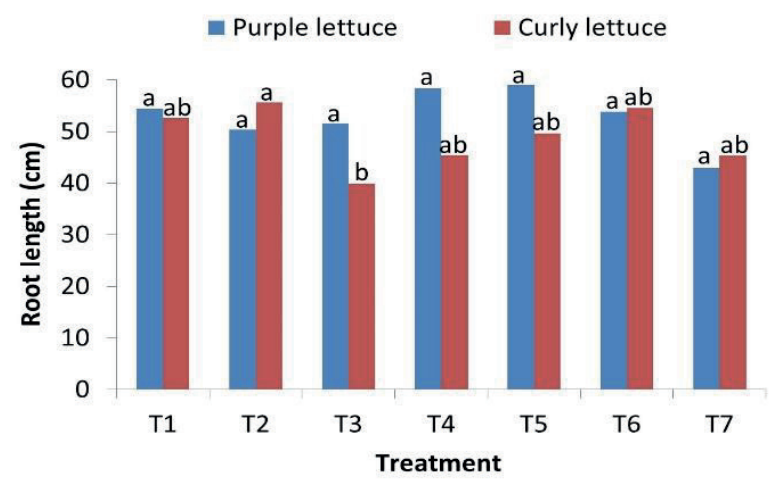

Curly lettuce showed higher RL values in the treatment with water from UFRB (T2), which did not differ from that using fresh water (T1). A significant difference in RL was found between the use of reject from Cruz das Almas and the control (T1), and no difference was found using the other types of water (Figure 7A). No significant statistical differences were found for the RL of the purple lettuce (Figure 7B).

The increase in nutrient solution salinity with the use of brackish waters did not significantly affect root length (RL) in any type of water studied, 
demonstrating that the reduction in the plants rather was a result of the salinity effect on the shoots than on the roots. Similar results with hydroponic lettuce have been reported by Alves et al. (2011), Filgueiras et al. (2002), Paulus et al. (2010), Soares et al. (2007), and Tas et al. (2005).

Symptoms of toxicity were observed in lettuce plants grown using brackish waters and desalination reject, which was probably due to the content of salts in the waters, leading to higher concentrations of toxic ions in the leaves and causing a thin chlorotic line on the leaf edges in the curly lettuce and tipburn symptoms in the purple lettuce.

At the highest salinity levels, plants of curly lettuce 'Verônica' and purple lettuce 'Quatro Estações' were shorter, more coriaceous, and showed a darker green color. Thin chlorotic lines appeared on the leaf edges in the curly lettuce subjected to treatments with water from UFRB (T2) and reject from Cruz das Almas (T3).

Symptoms of injuries such as burn of leaf edges and blades have been reported in plants subjected to brackish water (SANTOS et al., 2010).

Plants produced using brackish water from Sapeaçu (T4) showed no symptoms of toxicity; curly lettuce plants exhibited green color and large leaves, similar to those found in the treatment with fresh water (T1).

Curly lettuce plants subjected to treatment with reject from Sapeaçu (T5) showed a thin chlorotic line and chlorosis on the leaves.

The leaves were darker and smaller in lettuce plants subjected to the treatment with reject from Conceição do Coité (T6); curly lettuce leaves showed an intense green color, a thin chlorotic line on the edges, and a coriaceous aspect. Curly and purple lettuce plants in the treatment with water artificially salinated using $\mathrm{NaCl}$ (T7) had small leaves with an intense green color, a thin chlorotic line, and coriaceous aspect.

\section{Conclusions}

Brackish groundwaters from the deep tubular wells of UFRB and Sapeaçu, as well as from the desalination reject from Cruz das Almas in the Recôncavo of Bahia, proved to be technically viable for hydroponic lettuce production.

Relative lettuce production increased with the use of brackish groundwater from the wells of UFRB and Sapeaçu and the desalination reject from the well of Cruz das Almas.

Using desalination rejects from the wells of Conceição do Coité (Semi-arid region) and Sapeaçu (Recôncavo of Bahia) led to a reduction in the relative production and in symptoms of toxicity in lettuce plants.

\section{References}

ALBERONI, R. B. Hidroponia. São Paulo: Nobel, 1998. $102 \mathrm{p}$.

ALMEIDA, O. A. Informações meteorológicas do CNP. Cruz das Almas: EMBRAPA CNPMF, 1999. 35 p. (Documentos, 34).

ALVES, M. S.; SOARES, T. M.; SILVA, L. T.; FERNANDES, J. P.; OLIVEIRA, M. L. A.; PAZ, V. P. S. Estratégias de uso de água salobra na produção de alface em hidroponia NFT. Revista Brasileira de Engenharia Agrícola e Ambiental, Campina Grande, v. 15, n. 5, p. 421-498, 2011.

AUDRY, P.; SUASSUNA, J. A salinidade das águas disponíveis para a pequena irrigação no sertão nordestino: caracterização, variação sazonal, limitações de uso. Recife: $\mathrm{CNPq}$, Conselho Nacional de Desenvolvimento Científico e Tecnológico, 1995. 128 p.

BENJAMÍN, A. H.; MARQUES, C. L.; TINKE, C. The water giant awakes: an overview of water law in Brazil. Texas Law Review, Austin, v. 83, n. 7, p. 2185-2244, 2005.

BLAT, S. F.; SANCHEZ, S. V.; ARAÚJO, J. A. C.; BOLONHEZI, D. Desempenho de cultivares de alface crespa em dois ambientes de cultivo em sistema hidropônico. Horticultura Brasileira, Vitoria da Conquista, v. 29, n. 1, p. 135-138, 2011.

CARVALHO, P. C. M.; RIFFEL, D. B.; FREIRE, C.; MONTENEGRO, F. F. D. The Brazilian experience with 
a photovoltaic powered reverse osmosis plant. Progress in Photovoltaics: Research and Applications, New Jersey, v. 12, n. 5, p. 373-385, 2004.

CASAROLI, D.; FAGAN, E. B.; SANTOS, O. S.; BONNECARRĖRE, R. A. G.; NOGUEIRA FILHO, H. Desempenho de onze cultivares de alface em duas formas diferentes de canais de cultivo, no sistema hidropônico. Revista da Faculdade de Zootecnia, Veterinária e Agronomia, Uruguaiana, v. 10, n. 1, p. 25-33, 2003.

CIRILO, J. A. Políticas públicas de recursos hídricos para o semiárido. Estudos Avançados, São Paulo, v. 22, n. 63 , p. 61-82, 2008.

COSTA, A. M. B.; MELO, J. G.; SILVA, F. M. Aspectos da salinização das águas do aqüífero cristalino no Estado do Rio Grande do Norte, Nordeste do Brasil. Revista Águas Subterrâneas, São Paulo, v. 20, n. 1, p. 67-82, 2006.

DIAS, N. S.; SOUSA NETO, O. N.; COSME, C. R.; JALES, A. G. O.; REBOUÇAS, J. R. L.; OLIVEIRA, A. M. Resposta de cultivares de alface à salinidade da solução nutritiva com rejeito salino em hidroponia. Revista Brasileira de Engenharia Agrícola e Ambiental, Campina Grande, v. 15, n. 10, p. 991-995, 2011.

DOMINGUES, D. S.; TAKAHASHI, H. W.; CAMARA, C. A. P.; NIXDORF, S. L. Automated system developed to control $\mathrm{pH}$ and concentration of nutriente solution evaluated in hydroponic lettuce production. Computers and Electronics in Agriculture, Amsterdam, v. 84, n. 1, p. 53-61, 2012.

FILGUEIRAS, R. C.; TAKAHASHI, H. W.; BENINNI, E. R. Y. Produção de alface hidropônico em diferentes condutividades elétricas. Semina: Ciências Agrárias, Londrina, v. 23, n. 2, p. 157-164, 2002.

FURLANI, P. R.; SILVEIRA, L. C. P.; BOLONHEZI, D.; FAQUIN, V. Cultivo hidropônico de plantas. Campinas: IAC, 1999. 52 p. (Boletim técnico, 180).

HOGAN, D. J.; TOLMASQUIM, M. T. Human dimensions of globall environmental change; brazilian perspectives. Rio de Janeiro: Academia Brasileira de Letras, 2001. 390 p.

KARAGIANNIS, I. C.; SOLDATOS, P. G. Water desalination cost literature: review and assessment. Desalination, Amsterdam, v. 223, n. 1, p. 448-456, 2008.

LUZ, J. M. Q.; GUIMARÃES, S. T. M. R.; KORNDÖRFER, G. H. Produção hidropônica de alface em solução nutritiva com e sem silício. Horticultura Brasileira, Vitoria da Conquista, v. 24, n. 3, p. 295-300, 2006.

MARENGO, J. A.; BERNASCONI, M. Regional differences in aridity/drought conditions over Northeast Brazil: present state and future projections. Climatic Change, Berlim, v. 129, n. 1, p. 103-115, 2015.

MARTINEZ, H. E. P. Manual prático de hidroponia. Viçosa, MG: Aprenda Fácil, 2006. 271 p.

MONTENEGRO, S. G.; MONTENEGRO, A.; RAGAB, $R$. Improving agricultural water management in the semiarid region of Brazil: experimental and modelling study. Irrigation Science, Berlim, v. 28, n. 1, p. 301-316, 2010.

PAULUS, D.; DOURADO NETO, D.; FRIZZONE, J. A.; SOARES, T. M. Produção e indicadores fisiológicos de alface sob hidroponia com água salina. Horticultura Brasileira, Vitoria da Conquista, v. 28, n. 1, p. 29-35, 2010.

PORTO, E. R.; AMORIM, M. C. C. de; SILVA JÚNIOR, L. G. de A. Uso do rejeito da dessalinização de água salobra para irrigação da erva sal (Atriplex nummularia). Revista Brasileira de Engenharia Agrícola e Ambiental, Campina Grande, v. 5, n. 1, p. 111-114, 2001.

REBOUÇAS, A. C. A inserção da água subterrânea no sistema nacional de gerenciamento. Revista Brasileira de Recursos Hídricos, Porto Alegre, v. 7, n. 4, p. 39-50, 2002.

ROCHA, R.; SOARES, R. R. Water scarcity and birth outcomes in the Brazilian semiarid. Journal of Development Economics, Amsterdam, v. 112, n. 1, p. 7291, 2015.

SANTOS, A. N.; SOARES, T. M.; SILVA, E. F. F.; SILVA, D. J. R.; MONTENEGRO, A. A. A. Cultivo hidropônico de alface com água salobra subterrânea e rejeito da dessalinização em Ibimirim, PE. Revista Brasileira de Engenharia Agrícola e Ambiental, Campina Grande, v. 14, n. 9, p. 961-969, 2010.

SAVVAS, D. General introduction. In: SAVVAS, D.; PASSAM, H. C. Hydroponic production of vegetables and ornamentals. Athens: Embryo Publications, 2002. p. 15-23.

SEO, M. W.; YANG, D. S.; KAYS, S. J.; KIM, J.; WOO, J. H.; PARK, K. W. Effects of nutrient solution electrical conductivity and sulfur, magnesium, and phosphorus concentration on sesquiterpene lactones in hydroponically grown lettuce (Lactuca sativa L.). Scientia Horticulturae, Amsterdam, v. 122, n. 3, p. 369374, 2009.

SIDDIQI, M. Y.; KRONZUCKER, H. J.; BRITTO, D. T.; GLASS, A. D. M. Growth of a tomato crop at reduced nutriente concentrations as a strategy to limit eutrophication. Journal of Plant Nutrition, New York, v. 21, n. 9, p. 1879-1895, 1998. 
SILVA, E. R.; NOBREGA, O. S.; SILVA, R. H. Química transformações e aplicações. São Paulo: Ética, 2001. $408 \mathrm{p}$.

SILVA, V. P. R.; PEREIRA, E. R. R.; AZEVEDO, P. V.; SOUSA, F. A. S.; SOUSA, I. F. Análise da pluviometria e dias chuvosos na região Nordeste do Brasil. Revista Brasileira de Engenharia Agrícola e Ambiental, Campina Grande, v. 15, n. 2, p. 131-138, 2011.

SOARES, T. M. Utilização de águas salobras no cultivo da alface em sistema hidropônico NFT como alternativa agrícola condizente ao semiárido brasileiro. 2007. Tese (Doutorado em Irrigação e Drenagem) - Escola Superior de Agricultura Luiz de Queiroz. Universidade de São Paulo, Piracicaba.

SOARES, T. M.; DUARTE, S. N.; SILVA, E. F. F.; JORGE, C. Combinação de águas doce e salobra para produção de alface hidropônica. Revista Brasileira de Engenharia Agrícola e Ambiental, Campina Grande, v. 14, n. 7, p. 705-714, 2010.

SOARES, T. M.; DUARTE, S. N.; SILVA, E. F. F.; MELO, R. F.; JORGE, C. A.; OLIVEIRA, A. S. Experimental structure for evaluation of saline water use in lettuce hydroponic production. Irriga, Botucatu, v. 14, n. 1, p. 102-114, 2009.

SOARES, T. M.; SILVA, E. F. F.; DUARTE, S. N.; MELO, R. F.; JORGE, C. A.; BONFIM-SILVA, E. M.
Produção de alface utilizando águas salobras em sistema hidropônico. Irriga, Botucatu, v.12, n. 2, p.235-248, 2007.

SOARES, T. M.; SILVA, I. I. O.; DUARTE, S. N.; SILVA, E. F. F. Destinação de águas residuárias provenientes do processo de dessalinização por osmose reversa. Revista Brasileira de Engenharia Agrícola e Ambiental, Campina Grande, v. 10, n. 3, p. 730-737, 2006.

TAS, G.; PAPADANDONAKIS, N.; SAWAS, D. Responses of lettuce (Lactuca sativa L. var. longifolia) grown in a closed hydroponic system to $\mathrm{NaCl}-$ or $\mathrm{CaCl}_{2}-$ salinity. Journal of Applied Botany and Food Quality Angewandte Botanik, Gottingen, v. 79, n. 2, p. 136-140, 2005.

TSIOURTIS, N. X. Desalination and the environment. Desalination, Amsterdam, v. 141, n. 1, p. 223-236, 2001.

VAN OS, E. A. Closed soilless growing systems: a sustainable solution for Dutch greenhouse horticulture. Water Science and Technology, Oxford, v. 39, n. 3, p. 105-112, 1999.

VAN OS, E. A.; GIELING, T. H.; RUIJS, M. N. A. Equipment for hydroponic installations. In: SAVVAS, D.; PASSAM, H. C. (Ed.). Hydroponic production of vegetables and ornamentals. Athens: Embryo Publications, 2002. p. 103-141. 
